THE SUCCESSION OF FOSSIL FAUNAS IN THE KINDERHOOK BEDS AT BURLINGTON, IOWA.

BY

STUART WELLER 



\title{
THE SUCCESSION OF FOSSIL FAUNAS IN THE KINDERHOOK BEDS AT BURLINGTON, IOWA.
}

\author{
BY STUART WELLER.
}

The stratigraphic succession of the Mississippian beds at Burlington, Iowa, was first indicated by David Dale Owen* in 1852. At that time the Kinderhook stage or its equivalent had not been defined, but the lower portion of his general section, that portion which is now included in the Kinderhook, was described as follows:

5. Band of cellular, buff, magnesian limestone.

4. Oolitic limestone containing Gyroceras Burlingtonensis.

3. Dark gray argillaceous limestones (locally hydraulic?)

2. Buff, fine-grained siliceous rock, containing easts of Chonetes, Posidonomya, Allorisma, Spirifer, Phillipsia.

1. Ash colored, earthy marlites.

At that time Owen included all the strata down to the base of his No. 3, in the "Encrinital Group of Burlington." It is not possible to determine from his section the exact thickness attributed to each individual stratum recognized, but their aggregate is indicated in his table as about 100 feet, of which the lowest member, No. 1 is about 60 feet.

In 1858 Hall's report on the Geology of Iowa was published, and the following section is given of the rocks at Burlington of the Kinderhook stage, at that time referred to the "Chemung Group."†

*Rep. on Geol. Wis., Iowa and Minn, p. 92. (1852)

†Rep. Geol. Surv. Iowa, Vol. 1, pt. 1, p. 80. (1858.) 


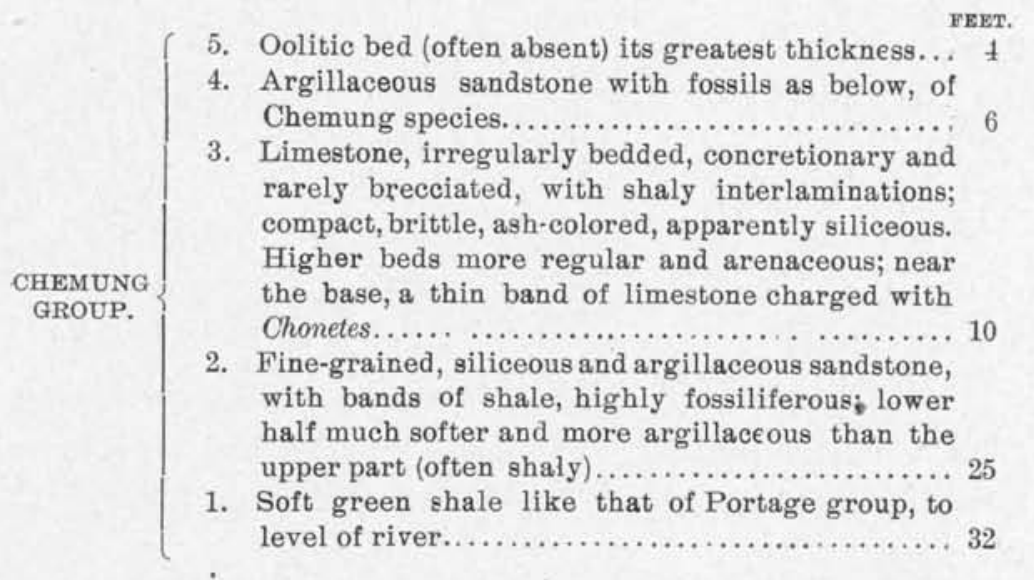

In 1860 C. A. White published a paper entitled, "Observations upon the Geology and Paleontology of Burlington, Iowa, and its Vicinity,"* in which the Kinderhook section at Burlington was described, and later, in 1870, while he was State Geologist, the section was again described in his official report. $\dagger$ In White's section seven beds were recognized as follows:

7. Impure limestone, sometimes magnesian, passing gradually into the Lower Burlington limestone..

6. Light gray oolitic limestone with uniform litho-

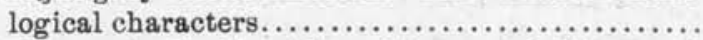

.5. Fine-grained yellowish sandstone much like parts of No.1, often crowded with casts of fossil shells.

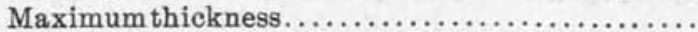

4. Dark gray compact limestone, sometimes slightly arenaceous. It breaks up into small fragments upon exposure, and is very fragmentary even when not exposed to the atmosphere. Maximum

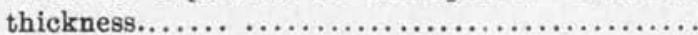

3. Band of oolite limestone about..................

2. Band of compact limestone everywhere crowded with Chonetes...............................

1. Fine-grained sandy shales, varying from bluish clay shale to fine-grained yellow sandstone. The upper portion of the bed quite fossiliferous. Greatest thickness actually exposed above river level 82 feet, its total thickness as estimated from well borings.

FEET.

$3-4$

2-4

7

$\frac{1}{4}$

*Jour. Bost. Soc. Nat. Hist., Vol, 7, pp. 209-235. (1860.)

- +Rep, Geol. Surv. Iowa, Vol. 1, pp. 192-193. (Des Moines, 1870.) 
In his report on Des Moines county, Keyes*, in 1895, gives the following section of the Kinderhook beds at Prospect Hill, a bluff on the river bank just south of the city of Burlington:

6. Limestone, buff, soft, sandy locally ................ FEET.

5. Limestone, white oolitic..................... 3

4. Sandstone, yellowish, soft, fine-grained, highly charged with easts of fossils......................... 6

3. Limestone, argillaceous, fine-grained, with often an oolitic band or thin bed of impure limerock at base.. 18

2. Sandstone, yellowish, soft, friable, clayey.......... 25

1. Shale, blue, argillaceous, shown by borings to extend 100 feet or more below river level (exposed)........6 60

In March, 1899, the writer spent some time in the field, studying the Kinderhook section at Burlington, in order to differentiate the fossil faunas of that age there represented, and the following section which seems best adapted to bring out the faunal succession, has been adopted as the result of observations made at that time. It differs from Hall's and from Keyes' sections only in dividing their No. 3, recognizing as a distinct bed their band of impure or oolitic limestone. It differs from White's section only in joining his Nos. 2 and 3, and in dividing his No. 1, the upper sandy, fossiliferous portion being recognized as a distinct bed:

7. Soft, buff, gritty limestone..............

6. White oolit'c limestone................... 2-4

5. Fine-grained, yellow sandstone ............. $6-7$

4. Fine-grained, compact, fragmental gray limestone. 12-18

3. Thin band of hard, impure, limestone filled with Chonetes; sometimes assooiated with a thin oolite band ................................ $\frac{1}{4}-\frac{n}{4}$

2. Soft, friable, argillaceous sandstone, sometime3 harder and bluish in color, filled with fossils in the upper portion, the most abundant of which is

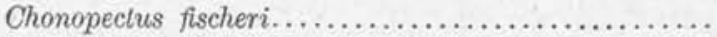

1. Soft blue argillaceous shale (exposed)............

The correlation of the Kinderhook beds at Burlington as recognized by these several observers is not a difficult matter, the preceding sections being but different interpretations or different arrangements of the same series of strata. In the following table these five sections are arranged side by side

*Geol. Surv. Iowa, Vol. 3, p. 433. (Des Moines, 1895.) 
in such a manner as to correlate the divisions recognized in each, the divisions of the several authors being indicated by numbers only:

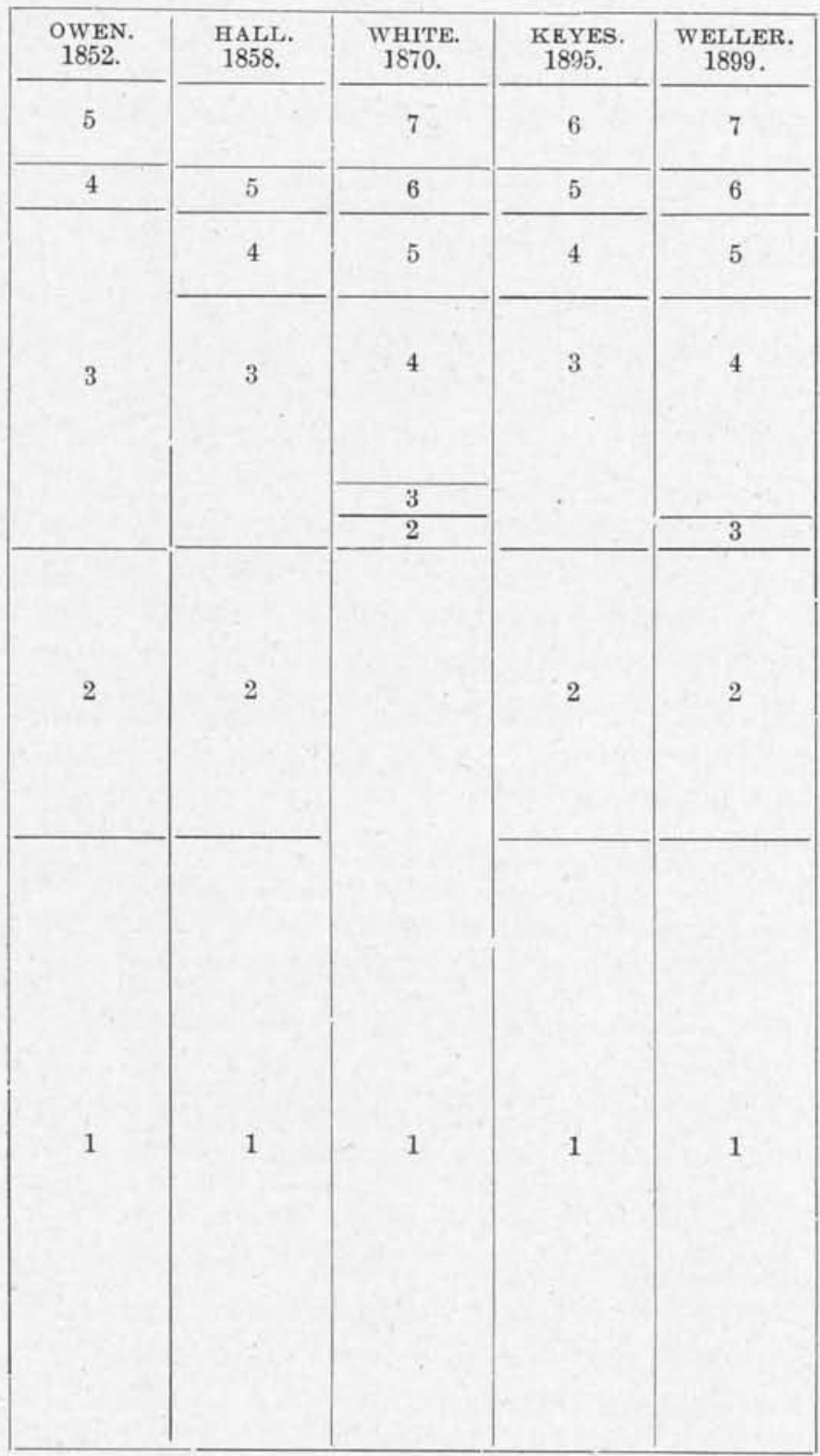

RIVER LEVEL. 
The fossils of the Kinderhook beds at Burlington, at one time attracted much attention from paleontologists and local collectors, but of late years they have usually been neglected. The first species described from any of the beds was Gyroceras burlingtonensis, described by Owen* in 1852, from the oolite bed No. 6 (Weller). A little later, in 1858, in his Paleontology of Iowa, Hall + described and illustrated a number of species of brachiopods and a few pelecypods from the "yellow sandstone " at Burlington.

The most important collection of Kinderhook fossils from Burlington that has been brought together was made by Dr. C. A. White when he was a resident of that city. The "White collection," which is now the property of the University of Michigan, formed the basis for several important papers devoted to the description of Burlington fossils by C. A. White $^{1}$, by C. A. White and R. P. Whitfield ${ }^{2}$, and by A. Winchell. ${ }^{3}$ In these papers many species were described but without illustrations, so that their identification by other observers and from other localities has always been exceedingly difficult or impossible.

During the preparation of the descriptions of New York Devonian pelecypods for the Paleontology of New York, Hall described and illustrated several of the Burlington "yellow sandstone" species that were related to New York Devonian species, the figures in most cases being drawn from the type specimens. More recently Keyes $\S$ has published upon some of the gasteropods from the Kinderhook beds at Burlington, but his identifications of the species were apparently not based on comparisons with the type specimens, and are evidently erroneous in some cases.

*Geol. Surv. Wis., Iow a and Minn., p. 581, tab. 5, fig. 10.

+Rep. Geol. Surv. Iowa, Vol. 1, pt. 2 .

1 Proc. Bost. Soc. Nat. Hist., Vol. 9, pp. 8-33. (1862)

2 Proc. Bost. Soc. Nat. Hist., Vol. 8, pp. 289-306. (1862.)

3 Proc. Acad. Nat. Scl. Phll , 1963, pp. 2-25. (1863) Proc. Acad. Nat. Sci. Phil., 1865, pp.109133. (1865.)

†Pal. N. Y., Vol. 5, pt. 1. (1884-1885,

\$Proc. Acad. Nat. Bci. Phll., 1889, p. 284 (1889), and Am. Geol., Vol. 5, p. 193. (1890.) 
In all the work which has been done in the past on the Kinderhook fossils at Burlington, little or no effort has been made to assign the species to their definite stratigraphic positions in the section. It has usually been deemed sufficient to refer a species to the "yellow sandstone, Burlington, Iowa." ignoring the fact that there are two yellow sandstones in the Kinderhook at that place, whose faunas are almost entirely distinct, there being only a small number of species common to the two beds. The fauna of the oolite bed can be more easily recognized from the literature, but even the fossils from this well marked horizon have often been recorded simply as coming from the "Kinderhook beds, Burlington, Iowa."

The present paper is an attempt to distribute the Kinderhook species from Burlington into their several faunas. It is based primarily upon the "White collection," for the use of which the writer is under the greatest of obligations to Prof. I. C. Russell of the University of Michigan, who has most generously loaned the Kinderhook portion of the collection for study. The specimens in the "White collection" are, for the most part, each marked with the number of the bed from which they were collected, but even without these numbers one is able to recognize by its lithological characters alone the bed from which each specimen is derived. In addition to the "White collection " Prof. Samuel Calvin has kindly loaned such material as he possessed, and Prof. J. A. Udden has furnished a small collection from bed No. 1. The collections made in the field by the writer have also added information'as to the stratigraphic position of some species.

In the following lists, all the species which have been recognized in each bed, will be given, with such notes on the species and on the faunal assemblages of species, as may seem necessary.

-Bed No. 1.--At the time the investigations of the Kinderhook faunas at Burlington were being carried on by Dr. White, no fossils had been found in this bed, and until recently it has 
been supposed to be entirely unfossiliferous. Since the opening of the clay pits of the Granite Brick Co., however, many fossils have been found at this horizon and the fauna is a most interesting assemblage of species. The fauna has not yet been critically studied, however, and as many of the species are as yet undescribed, it will, in most cases, be possible to refer them only to their proper genus. For the material illustrating this fauna, the writer is indebted entirely to Professor Calvin and Professor Udden.

\section{SPONGIAE-}

1. Dictyophyton sp. undet. A single specimen of a sponge belonging to the Dictyospongidoe has been observed. It is too imperfect for identification.

\section{CRINOIDEA-}

2. Crinoid stems. Not common.

\section{BRACHIOPODA-}

3. Lingula sp, undet.

4. Orbiculoidea sp. undet.

5. Schizophoria sp. undet. This is possibly an undescribed species allied to the S. striatula or S. swallovi.

6. Rhipidomella sp. ef. R. burlingtonensis H.

7. Productella sp. undet. This is a species closely allied to some of the Devonian forms.

8. Productus sp. undet. This a species of the semireticulatus type and is apparently allied to $P$. burlingtonensis though it may be a distinct species.

9. Productus laevicostus White. A single specimen which is seemingly referable to this species has been observed.

10. Eumetria altirostris White.

\section{PELECYPODA-}

11. Aviculopecten sp. undet. This is a large coarsely ribbe 1 species $3 \frac{1}{2}$ inches high.

GASTEROPODA-

12. Platyschisma sp. undet. A single specimen which possibly belongs to this genus.

13. Porcellia sp. undet. This is a large and apparently undescribed species, the largest individual observed being nearly six inches in diameter.

PTEROPODA-

14. Conularia sp. undet.

CEPHALOPODA-

15. Gomphoceras sp. undet. This species resembles some of the Devonian members of the genus.

\section{Crustacea-}

16. Palaeopalaemon newberryii Whitf.? This is probably the same crustacean that Whitfisld* identifisd from Kaskade, 3 miles west of Burlington,

*Am. Geol., Vol. 9, p. 237. 
Iowa, with his species $P$. newberryii. The species was first described from the Erie shale of Lake county, Ohio, and it is by no means certain that the Burlington specimens are identical with the types of the species or even that they belong to the same genus.

VERTEBRATA-

17. Fish remains. Several fragments of fish bones or spings have been observed. Plants-

18. Fragments of stems and leaves of plants are frequently met with.

The fauna of this bed is a most interesting one, it probably being the oldest of the Kinderhook faunas of the Mississippi valley. The presence of typical forms of the genus Productus give to the fauna a strong Carboniferous aspect, the undetermined species of Productella and Gomphoceras being the only members which are suggestive of the Devonian, unless the fish remains should show some such alliance. The fauna is really more strongly Carboniferous in aspect than is that of bed No. 2, whose large number of pelecypods are for the most part allied to Devonian species in New York. For the satisfactory study of the fauna, however, larger collections than are now available must be secured, and as soon as the necessary material is at hand, this fauna will be made the basis of one number of "Kinderhook Faunal Studies." *

Bed No. 2. + -This bed is the lower one of the two yellow sandstone horizons in the Kinderhook at Burlington, and it contains the most prolific fauna in the section. The fossils are most abundant, in fact are almost wholly restricted to the upper five or six feet of the bed, just below the thin band of impure limestone or bed No. 3. The sandstone is characterized by multitudes of individuals of Chonopectus fischeri (N. \& P.) and for this reason the bed may be designated as the Chonopectus sandstone. Usually the bed is a soft, friable, yellow grit or fine sandstone, in which the fossils are always preserved as casts, though in many cases the cavities left after the solution of the shell, have been

-Trans. St. Louis Acad Scl., Vol. 9, No. 2, and Ibld, Vol. 10, No. 3.

+ For a detalled description of the fauna of this bed, see Kinderhook Faunal Studies II. Fauna of the Chonopectus sandstone at Burlington, Iowa. Trans. St. Louls Acad. Scl., Vol, 10 , No. 3 , pp. $57-129$, plates I-IX. 
closed by pressure. At one locality on Flint river, this bed is represented by a highly fossiliferous, much harder, blue sandstone which has weathered along the joints into a soft yellow rock with characters similar to the usual exposures of the formation. From this occurrence it seems possible that the softness and yellow color of the bed as usually exposed, may be due to a weathered condition, but this could only be determined by extensive excavations.

The following list of species found in the Chonopectus sandstone is probably not absolutely complete and additional species will probably be discovered:

\section{CRINOIDEA-}

1. Joints of crinoid stems.

VERMES-

2. Worm burrows.

BRACHIOPODA-

3. Lingula membranacea Win.

4. Orbiculoidea capax (White.)

5. Orthothetes inaequalis (Hall).

6. Schizophoria swallowi (Hall).

7. Chonetes illinoisensis Worthen.

8. Chonetessp. cf. C. geniculata White.

9. Chonetes sp. undet.

10. Chonopectus fischeri (N. \& P.).

11. Productus semireticulatus Martin.

12. Productus cooperensis Swall?.

13. Productus laevicostus White.

14. Productella nummularis (Win.).

15. Pugnax striatocostata (M. \& W.) var.?

16. Rhynchonella sp. undet.

17. Eumetria altirostris (White).

18. Athyris corpulenta (Win.).

19. Spirifer subrotundatus Hall.

20. Spirifer biplicatus Ball.

21. Syringothyris extenuatus (Hall).

22. Reticularia cooperensis (Swal).

BRYOZOA-

23. Fenestella sp. undet.

PELECyPoda-

24. Aviculopecten tenricostus Win.

25. Aviculopecten caroli Win.

26. Pterinopecten cf. P. laetus Hall.

27. Pernopecten? sp. undet.

28. Leiopteria spinalata (Win.).

29. Avicula strigosa (White). 
30. Pleronites whitei (Win.).

31. Mytilarca occidentalis (W. \& W.).

32. My'ilarca fibristriata (W. \& W.).

33. Goniophora jenno (Win.).

34. Macrodon cochlearis Win.

35. Macrodon modesta (Win.).

36. Grammysia plena Hall.

37. Grammysia amygdalinus (Win.).

38. Edmondia burlingtonensis W. \& W.

39. Edmondia quadrata (W. \& W.).

40. Edmondia aequimarginalis Win.

41. Edmondia nitida Win.

42. Edmondia jejunus (Win.).

43. Sphenotus rigidus (W. \& W.).

44. Sphenotus bicarinatus (Win.).

45. Sphenotus irvensis (Wia.).

46. Sphenotus bicostatus Weller.

47. Spathella ventricosa (W. \& W.)

48. Cardiopsis megambonata Win.

49. Schizodus iowensis Weller.

50. Schizodus burlingtonensis Weller.

51. Cypricardinia sulcifera (Win.).

52. Glossites elliptica (Win.).

53. Glossites? burlingtonensis Weller.

54. Promacrus cuneatus Hall.

55. Posidonomya? ambigua Win.

\section{GASTEROPODA-}

56. Loxonema shumardana (Win.).

57. Loxonema oligospira Win.

58. Loxonema sp, undet.

59. Murchisonia quadricincta Win.

60. Strophostylus bivolve (W \& W.).

61. Sphaerodoma pinguis (Win.).

62. Naticopsis depressa Win.

63. Straparollus macromphalus Win.

64. Straparollus ammon (W. \& W.).

65. Straparollus angularis Weller.

66. Platyschisma barrisi (Win.).

67. Platyschisma depressa Weller.

68. Phanerotinus paradoxus Win.

69. Bellerophon bilabiatus W. \& W.

70. Bellerophon vinculatus W. \&. W.

71. Bellerophon panneus White?

72. Bucanopsis deflectus Weller.

73. Patellostium scriptiferus (White).

74. Porcellia crassinoda W. \&. W.

75. Porcellia obliquinoda White.

76. Porcellia rectinoda Win.

77. Dentalium grandaevum Win. 
PTEROPODA-

78. Conularia byblis White.

CePHaLOPODA-

79. Orthoceras whitei Win.

80. Orthoceras heterocinctum Win.

81. Orthoceras indianense Hall.

82. Phragmoceras expansum Win.

83. Cyrtoceras unicorne Win.

84. Agoniatites opimus (W. \& W.).

In some particulars this fauna of the Chonopectus sandstone exhibits 'strongly Devonian characteristics, but associated with this Devonian element there is another element of perhaps greater significance binding it to the Carboniferous. Of all the genera and species, the brachiopods are for the most part strongly Carboniferous in aspect. The abundance of Productus is particularly a Carboniferous characteristic of the fauna, as is also the presence of Syringothyris. Of the two species of Spirifer one, S. subrotundatus, with its completely plicated shell and with the plications on the lateral slopes bifurcating, is strongly Carboniferous in aspect, while $S$. biplicatus, on the other hand, with its excessively elongate hinge-line, has just as strong a Devonian aspect. The presence of Productella may be considered as a Devonian element, and also Orthothetes inaequalis, which is so nearly like o. chemungensis.

The pelecypods have quite a different story to tell, and from a study of this portion of the fauna alone, one would, perhaps, be justified in identifiying it as of Devonian age. All of the nineteen genera, with the exception of two, Promacms and Avicula, have numerous representatives in the Devonian faunas of eastern North America, particularly in the Chemung faunas of New York and Pennsylvania, and several 'of the genera have no representation later than the Kinderhook. Promacrus is a genus which is represented in America only in the Kinderhook, and in Europe it has been noted only in Belgium from near the base of the Carboniferous. Avicula is in general a later genus. Not only are most of the pelecypod genera abundantly represented in the Devonian, but in 
several instances the species in the Chonopectus sandstone are so nearly like species in the Chemung of New York, that it is largely a matter of personal opinion as to whether they are really distinct or not.

The gasteropods and cephalopods are also for the most part of Devonian types, with no strikingly Carboniferous characteristics. The genus Agoniatites has not previously been recognized outside the Devonian, and Orthoceras whitei is a very ancient type, being related to the Silurian $O$. annulatum.

Taken as a whole, a larger number of the species recognized in the fauna have Devonian and not Carboniferous relationships, but this is not sufficient evidence upon which to establish the Devonian age of the fauna. In general, in paleontologic interpretation, the initiation of a new invertebrate faunal element is of greater importance than the holding over of a much larger element from an older fauna, and on this principle, the strongly Carboniferous element among the brachiopods of the Chonopectus sandstone, is to be considered as weightier evidence than the hold-over pelecypods and cephalopods.

In any study of the Kinderhook faunas it must always be kept in mind that they are on the border line between the Devonian and Carboniferous, where a mingling of the two faunas and a gradual transition from the one to the other may be looked for.

Bed'No.'3.-This bed consists of two quite different parts, one of which is constantly present and another which is often absent. The persistent bed is a hard, impure limestone composed almost exclusively of individuals of a single small species of Chonetes, all other fossils being rare and but a small number of species being present at all. The following is a list of the species which have been recognized:

BRACHIOPODA-

1. Orthothetes ef. O. inatqualis (Hall).

2. Rhipidomella burlingtonensis (Ball).

3. Chonetes sp. ef. C. geniculata White.

4. Chonopectus fischeri (N. \& P.). 
In some places, there lies above this Chonetes bed an oolitic limestone layer, which if it were persistent would be deserving of separate recognition. White did recognize it as a distinct member in his section. It has a thickness of but about three inches and is always associated with the Chonetes bed, and for these reasons the two beds have been placed together in this paper, although no species of fossils have been observed to be common to both. The following species have been recognized from this oolite, all the specimens being preserved in the "White collection":

PELECYPODA-

1. Aviculopecten iowensis Miller.

2. Microdon leptogaster Win.

\section{GASTEROPODA-}

3. Holopea subconica Win.

4. Holopella mira Win.

Bed No. 4.- This bed is a fine-grained, compact, brittle, gray limestone with a conchoidal fracture. In its outerops it is always fragmental, being broken into irregularly shaped masses which rarely have any dimension greater than six inches. In its lithologic characters this limestone has the appearance of a lithographic stone, and is in this particular almost identical with the Louisiana limestone at Louisiana, Missouri. Judging from the lithologic characters alone, one would be entirely justified in considering this bed as a northern extension of the Louisiana limestone.

The fauna of the bed is not a prolific one so that no entirely satisfactory comparison between it and the fauna of the Louisiana limestone can be made. The species of Syringothyris in this bed at Burlington, which has been named S. halli by Winehell, seems to be identical with $S$. hannibalensis (Swallow) from Louisiana, the only conspicuous difference being in size, the Burlington specimens being much smaller than those from Louisiana. None of the remaining species at Burlington have been recognized at Lnuisiana. The following species have been identified: 
BRACHIOPODA-

1. Chonopectus fischeri (N. \& P.).

2. Rhynchonella heteropsis Win.

3. Rhynchonella unica Win.

4. Rhynchopora pustulosa (White).

5. Pugnax striaticostata (M. \& W.).

6. Syringothyris halli Win.

Bed No. 5.-In its upper portion, bed Nò. 4 becomes more and more arenaceous until it merges somewhat gradually into the upper "yellow sandstone" which constitutes bed No. 5 . In the transition layers between the well defined limestone below and the yellow sandstone above, no fossils have been observed, but in the sandstone itself fossils are sometimes extremely abundant. The fauna is quite distinct from that of the Chonopectus sandstone below, only two species being common to the two beds. The fossils from this upper sandstone may be always recognized by their condition of preservation and by the character of the sediment, this sandstone being denser and of a lighter color than that below. In both beds the fossils are always in the form of casts, but in the lower formation the cavities left by the solution of the calcareous matter of the shells and other fossils, have usually been closed by pressure, while in the upper sandstone the cavities remain open. In size the species occurring in this upper sandstone contrast somewhat strongly with those below, a large proportion of the species being diminutive.

The following species have been recognized in the fauna of this bed:

BRACHIOPODA-

1. Leptaena rhomboidalis (Wilck).

2. Orthothetes inaequalis (Hall).

3. Productus arcuatus Hall.

4. Productus parvulus Win.

5. Productus morbillianus Win.

6. Camarophorella lenticularis (W. \&. W.).

7 Dielasma allei (Win )

8. Spirifer marionensis.Shum.

9. Spirifer centronatus Win.

10. Spirifer sp. undet.

11. Reticularia cooperensis (Swall).

12. Cyrtina acutirostris (Shum.)? 


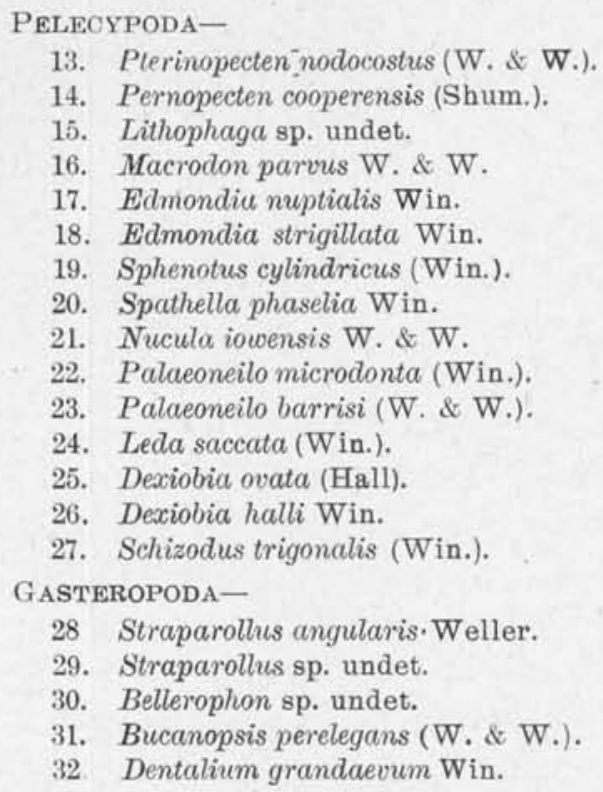

In this fauna Spirifer marionensis and Cyrtina acutirostris, two species which are particularly abundant in the Louisiana limestone, make their first appearance in the Burlington section. Spirifer marionensis becomes much more abundant in the succeeding oolite bed, but Cyrtina acutirostris has not been observed elsewhere in the section. The brachiopod element in the fauna is predominantly Carboniferous in aspect, but the pelecypods still continue to exhibit Devonian affinities in such genera as Pterinopecten and Palaeoneilo, though this more ancient element in the fauna is far less conspicuous than in the Chonopectus sandstone fauna.

Bed No. 6. - Succeeding the upper yellow sandstone, there is a conspicuous bed of white oolitic limestone which is quite sharply defined both below and above. Fossils are abundant and are often most beautifully preserved. The following species have been observed:

Corals-

1. Zaphrentis sp. undet.

BRACHIOPODA-

2. Leptaena rhomboidalis (Wilck).

3. Orthothetes inflatus (W. \& W.).

7 G Rep 

4. Chonetes logani N. \& P.
5. Chonetes illinoisensis Worthen.
6. Productus arcuatus Hall.
7. Productella concentricus Hall.
8. Schizophoria subelliptica (W. \& W.).
9. Rhipidomella sp. undet.
10. Dielasma allei (Win.).
11. Spirifer marionensis Shum.
12. Athyris crassicardinalis White.

PeLECYPODA-

.13. Pernopecten circulus (Hall).

14. Conocardium pulchellum W. \&. W.

\section{GASTEROPODA-}

15. Straparollus obtusus Hall.

16. Pleurotomaria quinquesulcata Win.

17. Loxonema sp. undet.

18. Capulus sp. undet.

\section{CEPHALOPODA-}

19. Orthoceras indianensis Hall.

20. Gyroceras burlingtonensis Owen.

In this fauna of the oolitic limestone the Devonian elements have practically disappeared.

Bed No. 7.-The topmost bed of the Kinderhook at Burlington, immediately beneath the Burlington limestone, is a brown, porous, magnesian limestone. Fossils are not abundant and those that are present are usually more or less imperfectly preserved. The following species have been observed:

\section{CORALS-}

1. Leptopora typa Win.

BRACHIOPODA-

2. Orthothetes inflatus (W. \& W.).

3. Orthothetes inaequalis (Hall)?

4. Productus punctatus Martin.

5. Camarophoria caput-testudinis (White).

6. Khynchonella persinuata Win.

7. Spiriferina solidirostris (White).

8. Nucleospira barrisi White.

\section{GASTEROPODA-}

9. Bellerophon pannens White.

10. Pleurotomaria mississippiensis W. \& W.

11. Igoceras undata (Win.).

12. Capulus paralius W. \& W.

13. Capulus vomerium (Win.). 
Conclusion.-The study of the Kinderhook faunas at Burlington has brought out quite strongly several important facts. First.-The "yellow sandstone" fauna of authors includes in reality two quite distinct faunas which occur in two entirely distinct yellow sandstone formations separated by a well defined limestone bed.

Second. - The Kinderhook series at Burlington represents a much longer time period than does the series of strata referred to this epoch elsewere, the lower beds being older than the Louisiana limestone which is placed at the base of the Kinderhook in Missouri.

Third.-Beds No. 1, No. 2, and No. 3 are pre-Louisianan in age, the earliest indication of the Louisiana limestone fauna being found in bed No. 4 which may be considered, with a fair degree of certainty, as the northern extension of the Louisiana limestone.

Fourth. - The succession of faunas exhibits a somewhat gradual transition from the earlier faunas with quite marked Devonian characters, to the later ones which are typically Carboniferous in aspect. The Devonian element in the faunas is for the most part exhibited by the pelecypods while the brachiopods are usually Carboniferous in aspect. This overlapping and intermingling of Devonian and Carboniferous faunal elements, makes it impossible to draw a sharp line separating the Devonian and Carboniferous systems such as is recognized in the continental interior between the Ordovician and Silurian in the Medina formation, and between the Silurian and Devonian in the Waterlime formation. The DevonianCarboniferous dividing line is more nearly analagous with the Cambrian-Ordovician division. 
i 